European

Thyroid Journal
Eur Thyroid J 2012;1:211-212

DOI: $10.1159 / 000345651$
Published online: December 8, 2012

\title{
In memoriam Professor Aldo Pinchera (1934-2012)
}

Professor Aldo Pinchera passed away on 11th October 2012 at the age of 78. Italian endocrinology has lost a great mentor, one of the founders of endocrinology in Italy and one of its greatest ambassadors in the world.

Aldo Pinchera graduated from the University of Rome in 1958, obtained the post-graduate degree in Endocrinology and Metabolic Diseases from the same university in 1961, and the Doctorate in Endocrinology in 1967. After training in several foreign institutions, such as the University of Marseille, the University of Barcelona, the Massachusetts General Hospital, Harvard Medical School, the Massachusetts Institute of Technology, he then moved to Pisa, where in 1980 he became Professor of Endocrinology until his retirement in 2009. He was then appointed Emeritus Professor of the University of Pisa. From 1981 to 2009 he directed the Post-Graduate School of Endocrinology and Metabolic Diseases at the University of Pisa. Among his numerous academic positions, Aldo Pinchera was Vice-President of the National University Council from 1998 to 2008. Throughout his career, he received numerous awards from the most important scientific institutions in the world. The most recent prize was the prestigious Lissitzky Career Award that he received in Pisa during the last annual meeting of the European Thyroid Association. Aldo Pinchera has been President (and Honorary Member) of the European Thyroid Association, President of the Italian Association of the Thyroid, Regional Coordinator for West Central
Prof. Aldo Pinchera

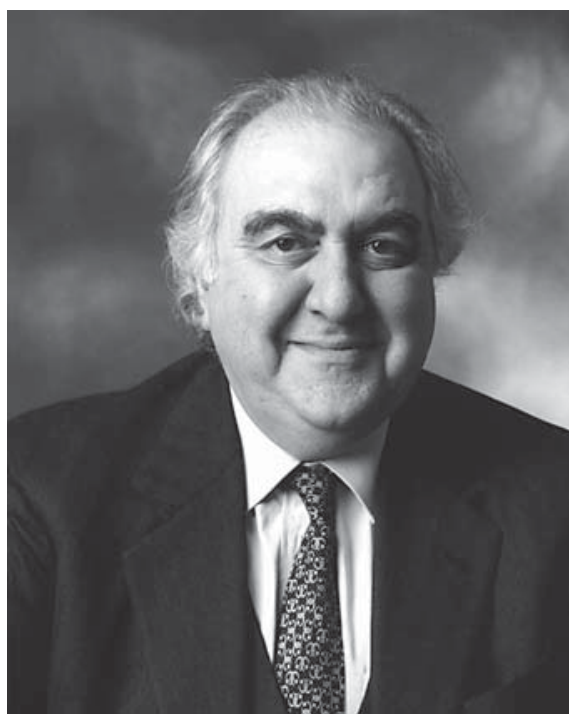

Europe and member of the Board of the International Council for Control of Iodine Deficiency Disorders, and Member of the European Community Thyroid Experts Panel for the consequences of the Chernobyl accident.

Aldo Pinchera had a wide editorial activity. He founded and directed for many years the international Journal of Endocrinological Investigation, the official journal of the Italian Society of Endocrinology, and the national journal l'Endocrinologo. He served in the Editorial Board

\begin{tabular}{ll}
\hline KARGER & ( 2012 European Thyroid Association \\
Published by S. Karger AG, Basel \\
Fax +41613061234 & $2235-0640 / 12 / 0014-0211 \$ 38.00 / 0$ \\
E-Mail karger@karger.ch & Accessible online at: \\
www.karger.com & www.karger.com/etj
\end{tabular}


of all the major international journals in the field of Endocrinology and Metabolism. His scientific interests ranged from thyroid diseases, particularly with regard to thyroid autoimmunity, thyroid cancer and endemic goiter, to parathyroid diseases and calcium metabolism, to obesity. His scientific activity translated into the publication of more than 630 peer-reviewed papers in international journals, 10 international volumes as Editor or CoEditor, 36 chapters in international textbooks.

Moved by his insatiable desire to bring endocrine research forward through the creation of a solid international network, Aldo Pinchera, a bright and keen investigator, selected and promoted a number of capable fellows, thus creating the Pisan Endocrinology School, one of the strongest in Italy. Many of his pupils have reached positions as full professors in several Italian universities after spending long periods of research and training in prestigious institutions abroad. He has been inspirational for generations of young researchers. His intelligence and his drive were contagious for young (and less young) fellows in Pisa and throughout Italy. His wisdom represented a reference point for a good advice or suggestion in troubled times or difficult situations. We cannot believe that we cannot give him a call any longer to discuss any kind of issue with him.

We miss Aldo and will continue to miss him. We have lost our Mentor. The Endocrine Community has lost one of the giants in this field. His achievements will continue to live after his death. He will live in our hearts forever.
Luigi Bartalena
Luca Chiovato
Gianfranco Fenzi
Claudio Marcocci
Stefano Mariotti
Enio Martino
Furio Pacini
Paolo Vitti
on behalf of all Aldo Pinchera's pupils 